\title{
(2) OPEN ACCESS \\ Disseminated Mycobacterium simiae and Mycobacterium avium infection causing an immune reconstitution inflammatory syndrome in a female patient with HIV infection
}

\author{
Jacqueline Alexandra Bachofner, ${ }^{1}$ Kristian Ikenberg, ${ }^{2}$ Bettina Schulthess, ${ }^{3}$ \\ Johannes Nemeth ${ }^{1}$
}

${ }^{1}$ Department of Infectious Diseases and Hospital Epidemiology, University Hospital Zurich, Zurich, Switzerland

${ }^{2}$ Institute of Pathology and Molecular Pathology, University Hospital Zurich, Zurich, Switzerland

${ }^{3}$ Institute of Medical Microbiology, University of Zurich, Zurich, Switzerland

\section{Correspondence to}

Dr Jacqueline Alexandra Bachofner;

Jacqueline.bachofner@hispeed. ch

Accepted 11 May 2021

Check for updates

(c) BMJ Publishing Group Limited 2021. Re-use permitted under CC BY-NC. No commercial re-use. See rights and permissions. Published by BMJ.

To cite: Bachofner JA Ikenberg K, Schulthess B, et al. BMJ Case Rep

2021:14:e241037.

doi:10.1136/bcr-2020-

241037

\section{SUMMARY}

This case study discusses the management of a disseminated Mycobacterium simiae and Mycobacterium avium infection causing an immune reconstitution inflammatory syndrome in a 52-year-old woman with HIV infection. Disseminated M. avium infections have extensively been described in HIV patients; however, reports of infections with $M$. simiae are rare. Treatment of M. simiae infections is challenging due to its high rates of natural drug resistances, and thus far, no standard treatment regimen exists.

\section{BACKGROUND}

Mycobacterium avium has been described frequently as a cause of pulmonary infection in patients with chronic pulmonary disease (eg, bronchiectasis and cystic fibrosis) and disseminated infection in patients with HIV/AIDS. ${ }^{1}$ Treatment recommendation for $M$. avium consists of a threedrug regimen including macrolide, rifamycin and ethambutol. ${ }^{2}$ Mycobacterium simiae is a rare, slowly growing non-tuberculous mycobacterium (NTM), which was first discovered in monkeys in 1965 by Karassova et al (simia is the Latin word for monkey). ${ }^{1-3} M$. simiae has been reported in several regions of the world, mainly the USA and in the Middle East (Lebanon, Iran, Reunion Island, Israel and Texas). ${ }^{4-8}$ In the late 1990 s, a nosocomial pseudo-outbreak in a hospital in Texas was documented; the reservoir was a contaminated water supply. ${ }^{9}$ In most published cases, M. simiae is reported to be an opportunistic pathogen-causing infections in immunocompromised patients (especially AIDS) or in patients with pre-existing pulmonary diseases. ${ }^{4} 10$ However, there are cases of infections reported in immunocompetent patients: Cruz et $a l^{11}$ describe a case of a healthy child with M. simiae lymphadenitis. M. simiae skin infection is reported in an immunocompetent adult due to an iatrogenic infection. ${ }^{12}$ Balkis $e t ~ a l^{13}$ describe a case of disseminated M. simiae infection in an immunocompetent 83-year-old man without pre-existing pulmonary disease with immune senescence being a possible risk factor. Treatment of M. simiae infections is challenging because of multiple intrinsic drug resistances, especially against tuberculostatic drugs. ${ }^{1415}$ Treatment regimen for M. simiae infections containing a macrolide (azithromycin or clarithromycin), a fluorochinolone (eg, moxifloxacin) and a third antibiotic class (eg, clofazimine, streptomycin or an amionglycoside such as amikacin) have been used, but standardised treatment recommendations to this point are non-existent.

\section{CASE PRESENTATION}

A 52-year-old woman of African descent was newly diagnosed with AIDS due to a HIV type 1 infection in December 2019. At that time, the CD4 count was 13 cells $/ \mu \mathrm{L}$, and the viral load was about 240 000 copies/mL. In January 2020, an antiretroviral therapy (ART) with Descovy (emtricitabin +tenofoviralafenamid) and Tivicay (dolutegravir) was initiated. Bactrim (cotrimoxazol) was prescribed for pneumocystis prophylaxis. As part of the initial evaluation, the patient was tested for other infectious diseases: serological testing for hepatitis $\mathrm{A}$ indicated a past infection, hepatitis $\mathrm{B}$ and hepatitis C serological panels were negative, Cytomegalovirus (CMV) and Ebstein-Barr virus (EBV) PCR were also negative.

Two weeks after the beginning of ART, the patient presented with new onset of fever $\left(39^{\circ} \mathrm{C}\right)$, fatigue and weight loss. Personal history and family history were unremarkable. No recent travel history. She reported regular medication intake. Physical examination did not show any abnormal findings apart from the elevated axillary temperature. At this time, leucocyte count was $1.74 \mathrm{G} / \mathrm{L}$, haemoglobin was 67 $\mathrm{g} / \mathrm{L}$ and the platelet count was $217 \mathrm{G} / \mathrm{L}$. C reactive protein was $109 \mathrm{mg} / \mathrm{L}$. Body mass index at presentation $17.2 \mathrm{~kg} / \mathrm{m}^{2}$. Chest radiograph and chest CT did not show any pulmonary infiltrates. Unspecific mediastinal lymphadenopathy was seen on chest CT. Urine analysis did not show signs of urinary tract infection. After another 2 weeks, the patient developed bilateral, painful, inguinal lymphadenopathy. A gynaecological infection or a gynaecological tumour as a cause of the lymphadenopathy were excluded after normal smear results and a normal pelvis MRI. Despite an empiric treatment with cefepime and doxycycline for 2 weeks, the patient was still febrile without clinical improvement.

Repeated blood cultures were performed without signs of bacterial growth. No other cause of the fever could be identified. Multiple examinations were initiated but no viral, bacterial or fungal infection 


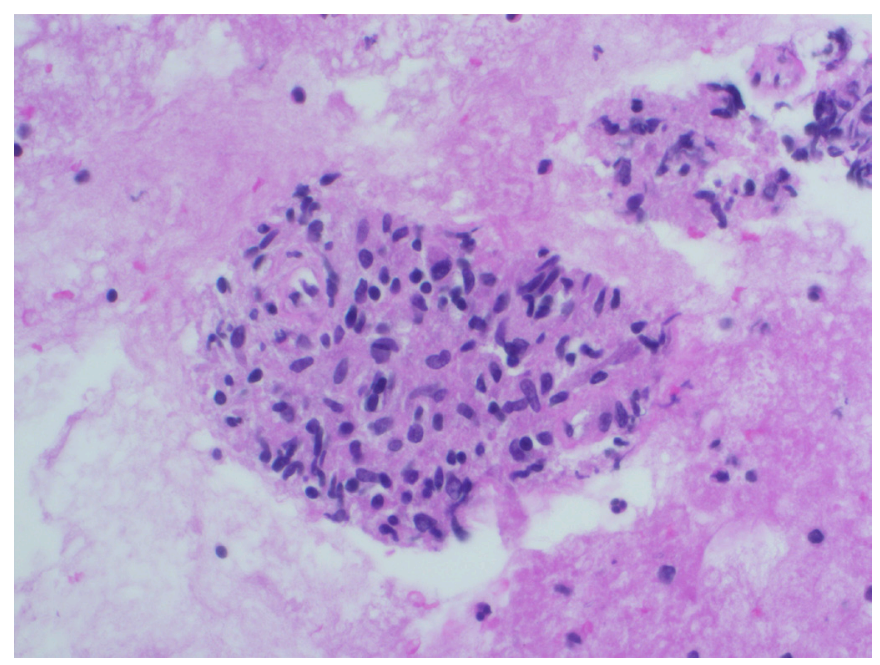

Figure 1 Cell block preparation from the fine needle aspiration (FNA) of an inguinal lymph node: granulomatous inflammation with typical aggregation of epithelioid histiocytes (H\&E stain; 400x).

was identified: CMV PCR and EBV PCR were still negative, EBV and toxoplasmosis serologies indicated a past infection, Cryptococcus neoformans antigen was negative and sputum PCR for atypical bacterial pneumonia was negative. Because of neutropaenia, a bone marrow biopsy was performed, which showed reactive changes compatible with HIV infection.

After additional 2 weeks, M. simiae grew in citrate blood cultures, bone marrow, lymph node, sputum and stool cultures. An inguinal lymph node biopsy confirmed granulomatous inflammation and copious acid-fast bacilli (figure 1). In one blood culture and in the lymph node biopsy M. avium was isolated in addition to M. simiae.

\section{TREATMENT}

Having diagnosed a disseminated mycobacterial infection with M. simiae and M. avium, we started a treatment regimen with azithromycin (oral $500 \mathrm{mg}$ once daily), moxifloxacin (oral 400 $\mathrm{mg}$ once daily) and amikacin (intravenous $15 \mathrm{mg}$ per $\mathrm{kg}$ ones daily). After 4 weeks, based on the drug susceptibility testing results (table 1), we switched from intravenous amikacin to clofazimine (oral $50 \mathrm{mg}$ twice daily). Because of persistent fever, we repeatedly performed additional diagnostic rounds searching for other infections, but to no avail. Therefore, we started treatment with prednisone $20 \mathrm{mg}$ for a presumptive immune reconstitution syndrome. The clinical condition of the patient improved rapidly, and we were able to gradually taper the prednisone dosage over weeks. The inguinal lymphadenopathy improved fast as well.

\section{OUTCOME AND FOLLOW-UP}

Blood culture showed mycobacterial growth up to 1 month after treatment start and turned negative after 7 weeks. Serial ECG monitoring was performed without prolongation of the correctet QT interval (QTc). The patient reported significant improvement in general condition.

\section{DISCUSSION}

Here, we present a case with unmasking immune reconstitution inflammatory syndrome (IRIS) caused by a disseminated mycobacterial infection with M. simiae and M. avium in a 52-year-old woman with HIV infection 4 weeks after starting ART. Given
Table 1 Antibiotic susceptibility patterns of $M$. simiae and $M$. avium

\begin{tabular}{|c|c|c|c|c|}
\hline \multirow[b]{2}{*}{ Drug } & \multicolumn{2}{|l|}{ M. simiae } & \multicolumn{2}{|l|}{ M. avium } \\
\hline & MIC (mg/L) & Interpretation & MIC (mg/L) & Interpretation \\
\hline Clarithromycin & 4 & 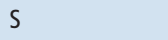 & 4 & $s$ \\
\hline Ethambutol & $>16$ & na & 16 & na \\
\hline Rifampicin & $>8$ & $\mathrm{R}$ & 1 & S \\
\hline Rifabutin & $>8$ & $\mathrm{R}$ & 0.25 & $\mathrm{~S}$ \\
\hline Amikacin & 16 & $S$ & 8 & $\mathrm{~s}$ \\
\hline Moxifloxacin & 0.5 & $S$ & 1 & S \\
\hline Clofazimine & $\leq 1$ & na & $\leq 1$ & na \\
\hline Linezolid & $>64$ & $\mathrm{R}$ & 16 & I \\
\hline Doxycyline & $>16$ & $\mathrm{R}$ & $>16$ & $\mathrm{R}$ \\
\hline $\begin{array}{l}\text { Trimethoprim/ } \\
\text { sulfamethoxazole }\end{array}$ & $2 / 32$ & $\mathrm{~s}$ & $2 / 38$ & $\mathrm{~s}$ \\
\hline Isoniazid & 8 & na & $>8$ & na \\
\hline
\end{tabular}

Minimal inhibitory concentrations (MIC) were determined by broth microdilution as recommendedby CLSI using Sensititre SLOWMYCOI plates (ThermoFisher, Waltham, MA). ${ }^{25}$ ClofazimineMIC was measured by quantitiative MGIT testing. ${ }^{26}$

Interpretation according to species-independent CLSI breakpoints for slowly growing NTM. ${ }^{25}$

I, intermediate; $M$. avium, Mycobacterium avium; MIC, minimal inhibitory concentrations; M. simiae, Mycobacterium simiae; na, no breakpoints available; $\mathrm{R}$, resistant; $\mathrm{S}$, susceptible.

the temporal association of the beginning of the symptoms and introduction of the ART, and the extent of disease, it is suggestive that the patient suffered from disseminated $M$. simiae and $M$. avium infection already at the time of HIV diagnosis. Therefore, we hypothesise that the development of symptoms was mostly due to beginning IRIS after successful suppression of the HI viral load and immune reconstitution. Mycobacterial cultures are not routinely performed at the time of diagnosis, and therefore, we cannot prove whether the mycobacterial infection was ongoing at the time of HIV diagnosis or not.

The treatment for presumptive IRIS encompasses first treatment against the pathogen to reduce pathogen load and second slowing the fulminant immune response, ideally without hampering the 'normal' recovery of the immune system. ${ }^{16-18}$

The pathogen-directed therapy against $M$. simiae is complicated since optimal treatment regimens have not been studied. The standard treatment regimen for $M$. avium infections, consisting of a macrolide, ethambutol and a rifamycine, is not recommended for $M$. simiae infections due to high rates of resistances. Overall, M. avium seems to be more susceptible than $M$. simiae to antibiotics. This is consistent with the results from our patient, shown in table 1 . For M. simiae infections, a combination of three drugs including a macrolide seems to be favourable. ${ }^{19}{ }^{20}$ Based on the in vitro investigations of van Ingen et al, moxifloxacin, a macrolide and a third antibiotic class (eg, clofazimine and streptomycin, an aminoglycoside such as amikacin) should be included in treatment regimens for a $M$. simiae infection. ${ }^{21}$ Azithromycin and clarithromycin are assumed to be equally effective. ${ }^{2023}$ Although moxifloxacin, clarithromycin and amikacin or clofazimine is not the standard treatment regimen for $M$. avium infections, M. avium mostly is also susceptible to

\section{Learning points}

Mycobacterium simiae can cause severe disseminated disease in AIDS patients.

- Immune reconstitution due to antiretroviral treatment is a diagnostic and therapeutic challenge. 
these drugs, as shown in our case (table 1). For lung infections and disseminated NTM infections treatment duration is recommended 12 months after sputum culture conversion. ${ }^{20}$

The IRIS component of the infection was treated with prednisone after excluding other, active infections multiple times. ${ }^{24}$ The treatment with prednisone led to dramatic clinical improvement, cessation of fever and malaise and, subsequently, normalised appetite and weight gain.

Acknowledgements We would like to acknowledge Dr med. Nadia EberhardKuhn for explaining the informed consent form to the patient.

Contributors $J A B$ and JN drafted the initial manuscript and reviewed and revised the manuscript. JAB performed literature search. BS collected data for table 1. KI provided figure 1. All authors approved the final manuscript as submitted and agree to be accountable for all aspects of the work.

Funding The authors have not declared a specific grant for this research from any funding agency in the public, commercial or not-for-profit sectors.

Competing interests None declared.

Patient consent for publication Obtained.

Provenance and peer review Not commissioned; externally peer reviewed.

Open access This is an open access article distributed in accordance with the Creative Commons Attribution Non Commercial (CC BY-NC 4.0) license, which permits others to distribute, remix, adapt, build upon this work non-commercially, and license their derivative works on different terms, provided the original work is properly cited and the use is non-commercial. See: http://creativecommons.org/ licenses/by-nc/4.0/.

\section{REFERENCES}

1 Inderlied CB, Kemper CA, Bermudez LE. The Mycobacterium avium complex. Clin Microbiol Rev 1993;6:266-310.

2 Daley CL, Winthrop KL. Mycobacterium avium complex: addressing gaps in diagnosis and management. J Infect Dis 2020;222:S199-211. 222(Supplement_4).

3 Karassova V, Weissfeiler J, Krasznay E. Occurrence of atypical mycobacteria in Macacus rhesus. Acta Microbiol Acad Sci Hung 1965;12:275-82.

4 Hamieh A, Tayyar R, Tabaja $\mathrm{H}$, et al. Emergence of Mycobacterium simiae: A retrospective study from a tertiary care center in Lebanon. PLoS One 2018;13:e0195390.

5 Mortazavi Z, Bahrmand A, Sakhaee F, et al. Evaluating the clinical significance of nontuberculous mycobacteria isolated from respiratory samples in Iran: an often overlooked disease. Infect Drug Resist 2019;12:1917-27.

6 Coolen-Allou N, Touron T, Belmonte O, et al. Clinical, Radiological, and Microbiological Characteristics of Mycobacterium simiae Infection in 97 Patients. Antimicrob Agents Chemother 2018;62. doi:10.1128/AAC.00395-18. [Epub ahead of print: 2606 2018].

7 Lavy A, Yoshpe-Purer Y. Isolation of Mycobacterium simiae from clinical specimens in Israel. Tubercle 1982;63:279-85.
8 Conger NG, O'Connell RJ, Laurel VL, et al. Mycobacterium simae outbreak associated with a hospital water supply. Infect Control Hosp Epidemiol 2004;25:1050-5.

9 El Sahly HM, Septimus E, Soini H, et al. Mycobacterium simiae pseudo-outbreak resulting from a contaminated hospital water supply in Houston, Texas. Clin Infect Dis 2002;35:802-7.

10 Baghaei P, Tabarsi P, Farnia P, et al. Pulmonary disease caused by Mycobacterium simiae in Iran's national referral center for tuberculosis. I Infect Dev Ctries 2012;6:23-8.

11 Cruz AT, Goytia VK, Starke JR. Mycobacterium simiae complex infection in an immunocompetent child. J Clin Microbiol 2007:45:2745-6.

12 Piquero J, Casals VP, Higuera EL, et al. latrogenic Mycobacterium simiae skin infection in an immunocompetent patient. Emerg Infect Dis 2004;10:969-70.

13 Balkis MM, Kattar MM, Araj GF, et al. Fatal disseminated Mycobacterium simiae infection in a non-HIV patient. Int I Infect Dis 2009;13:e286-7.

14 van Ingen J, van der Laan T, Dekhuijzen R, et al. In vitro drug susceptibility of 2275 clinical non-tuberculous Mycobacterium isolates of 49 species in the Netherlands. Int J Antimicrob Agents 2010;35:169-73.

15 van Ingen J, Boeree MJ, Dekhuijzen PNR, et al. Clinical relevance of Mycobacterium simiae in pulmonary samples. Eur Respir J 2008:31:106-9.

16 Sharma SK, Soneja M. HIV \& immune reconstitution inflammatory syndrome (IRIS). Indian J Med Res 2011;134:866-77.

17 Kaplan JE, Benson C, Holmes KK. Guidelines for prevention and treatment of opportunistic infections in HIV-infected adults and adolescents: recommendations from CDC, the National Institutes of health, and the HIV medicine association of the infectious diseases Society of America. MMWR Recomm Rep 2009:58(RR4:1-207.

18 Meintjes G, Scriven J, Marais S. Management of the immune reconstitution inflammatory syndrome. Curr HIV/AIDS Rep 2012;9:238-50.

19 Jabbour J-F, Hamieh A, Sharara SL, et al. Mycobacterium simiae: harmless colonizer or deadly pathogen? PLOS Pathog 2020;16:e1008418.

20 Shulha JA, Escalante P, Wilson JW. Pharmacotherapy approaches in nontuberculous mycobacteria infections. Mayo Clin Proc 2019;94:1567-81.

21 van Ingen J, Totten SE, Heifets LB, et al. Drug susceptibility testing and pharmacokinetics question current treatment regimens in Mycobacterium simiae complex disease. Int J Antimicrob Agents 2012;39:173-6.

22 Griffith DE, Aksamit T, Brown-Elliott BA, et al. An official ATS/IDSA statement: diagnosis, treatment, and prevention of nontuberculous mycobacterial diseases. Am J Respir Crit Care Med 2007;175:367-416.

23 Stout JE, Floto RA. Treatment of Mycobacterium abscessus: all macrolides are equal, but perhaps some are more equal than others. Am J Respir Crit Care Med 2012;186:822-3.

24 Meintjes G, Wilkinson RJ, Morroni C, et al. Randomized placebo-controlled trial of prednisone for paradoxical tuberculosis-associated immune reconstitution inflammatory syndrome. AIDS 2010;24:2381-90.

25 CLSI. Performance standards for susceptibility testing of mycobacteria, Nocardia spp., and other aerobic Actinomyces. 1st ed. Wayne, PA: Clinical Laboratory Standards Institute, 2018

26 Hombach M, Somoskövi A, Hömke R, et al. Drug susceptibility distributions in slowly growing non-tuberculous mycobacteria using MGIT 960 TB exist. Int J Med Microbiol 2013;303:270-6

Copyright 2021 BMJ Publishing Group. All rights reserved. For permission to reuse any of this content visit https://www.bmj.com/company/products-services/rights-and-licensing/permissions/ BMJ Case Report Fellows may re-use this article for personal use and teaching without any further permission.

Become a Fellow of BMJ Case Reports today and you can:

- Submit as many cases as you like

- Enjoy fast sympathetic peer review and rapid publication of accepted articles

- Access all the published articles

- Re-use any of the published material for personal use and teaching without further permission

Customer Service

If you have any further queries about your subscription, please contact our customer services team on +44 (0) 2071111105 or via email at support@bmj.com.

Visit casereports.bmj.com for more articles like this and to become a Fellow 